Jurnal Adat dan Budaya, Vol.1, No.1 Tahun 2019

ISSN: E-ISSN 2615-6156, P-ISSN: 2615-6113

Jurnal Homepage: https://ejournal.undiksha.ac.id/index.php/JABI/index

\title{
Pengaruh Model Pembelajaran Snowball Throwing Berbasis Tri Hita Karana Terhadap Hasil Belajar IPA
}

\author{
I Putu Hary Anggara Citragotra ${ }^{1}, \mathrm{Ni}$ Wayan Arini ${ }^{2}$, Made Sumantri ${ }^{3}$ \\ 123Program Studi Pendidikan Guru Sekolah Dasar, Universitas Pendidikan Ganesha, Bali, Indonesia \\ E-mail: hary.anggara.citragotra@undiksha.ac.id
}

\begin{abstract}
Abstrak
Penelitian ini bertujuan untuk mengetahui perbedaan hasil belajar IPA antara kelompok siswa yang mengikuti pembelajaran dengan menggunakan model pembelajaran Snowball Throwing berbasis Tri Hita Karana dan kelompok siswa yang dibelajarkan pada siswa kelas III di SD Gugus IV Kecamatan Sawan Kabupaten Buleleng. Jenis penelitian ini adalah penelitian eksperimen semu dengan rancangan post test only control group design. Populasi penelitian ini adalah seluruh siswa kelas III di Gugus IV Kecamatan Sawan Kabupaten Buleleng. Sampel diambil dengan cara random sampling melalui teknik undian, tetapi yang diundi adalah kelas. Instrumen pengumpulan data yang digunakan dalam penelitian ini adalah tes hasil belajar IPA. Data dianalisis menggunakan statistik deskriptif dan Independent Sample t-test. Hasil pengujian hipotesis menunjukkan bahwa terdapat perbedaan yang signifikan pada hasil belajar IPA antara siswa yang belajar dengan Model Pembelajaran Snowball Throwing Berbasis Tri Hita Karana dan siswa yang dibelajarkan tidak dengan Model Pembelajaran Snowball Throwing Berbasis Tri Hita Karana. Besarnya thitung sebesar 2,533, sedangkan, tabel dengan dk $=54$ pada taraf signifikansi 5\% adalah 2,0. Hal ini berarti, $t_{\text {hitung }}$ lebih besar dari $t_{\text {tabel }}\left(t_{\text {hitung }}>t_{\text {tabel }}\right.$ ) sehingga $\mathrm{H}_{0}$ ditolak dan $\mathrm{H}_{1}$ diterima. Dengan demikian, dapat diinterpretasikan bahwa terdapat perbedaan yang signifikan pada hasil belajar IPA antara siswa yang belajar dengan Model Pembelajaran Snowball Throwing Berbasis Tri Hita Karana dan siswa yang tidak belajar dengan Model Pembelajaran Snowball Throwing Berbasis Tri Hita Karana pada siswa kelas III SD di Gugus IV Kecamatan Sawan Tahun Pelajaran 2016/2017
\end{abstract}

Kata Kunci: Snowball Throwing; Tri Hita Karana; Hasil Belajar IPA

\begin{abstract}
This study aims to determine the differences in science learning outcomes between groups of students participating in the study using the Snowball Throwing learning model based on Tri Hita Karana and groups of students who were taught to grade III students in elementary school Gugus IV, Sawan District, Buleleng Regency. This type of research is quasi-experimental research with a post-test only control group design. The population of this study was all class III students in Cluster IV of Sawan District, Buleleng Regency. Samples are taken by random sampling through lottery techniques, but the draw is class. The instrument of data collection used in this study is a test of science learning outcomes. Data were analyzed using descriptive statistics and Independent Sample t-test. The results of hypothesis testing show that there are significant differences in the learning outcomes of science between students who study with the Snowball Throwing Learning Model Based on Tri Hita Karana and students who are not taught by Tri Hita Karana's Snowball Throwing Learning Model. The magnitude of tcount is 2.533, whereas, $\mathrm{t}$ table with $\mathrm{dk}=54$ at the significance level of $5 \%$ is 2.0 . This means, tcount is greater than $\mathrm{t}$ table (tcount $>\mathrm{ttable}$ ) so that $\mathrm{H} 0$ is rejected and $\mathrm{H} 1$ is accepted. Thus, it can be interpreted that there are significant differences in science learning outcomes between students studying with the Snowball Throwing Learning Model Based on Tri Hita Karana and students who did not study with Tri Hita Karana's Snowball Throwing Learning Model in Grade III Elementary School students in Cluster IV District Sawan 2016/2017 Academic Year
\end{abstract}

Keywords: Snowball Throwing; Tri Hita Karana; Science Learning Outcomes

\section{PENDAHULUAN}

Peningkatkan Pendidikan yang terjadi saat ini menjadi perhatian pemerintah karena kecerdasan bangsa tergantung pada suatu pendidikan. Semakin baik mutu pendidikan yang ada, maka akan semakin baik pula generasi penerus bangsa yang dihasilkan. Dalam dunia pendidikan sangat perlu dan penting untuk mengetahui bagaimana sebenarnya mutu pendidikan yang ada di negara kita saat ini khususnya Indonesia. 
Shoimin (2014) menyatakan bahwa pada saat ini pendidikan terus mengalami pembaharuan kurikulum. Kurikulum adalah seperangkat rencana dan pengaturan mengenai tujuan, isi, dan bahan pelajaran serta cara yang digunakan sebagai pedoman penyelenggaraan kegiatan pembelajaran untuk mencapai tujuan pendidikan tertentu. Seperti yang kita ketahui kurikulum KTSP disempurnakan lagi menjadi kurikulum 2013. Kurikulum 2013 ini dikembangkan dengan tujuan mewujudkan tujuan pendidikan nasional. Di dalam kurikulum 2013, terutama di dalam materi pembelajaran terdapat materi yang dirampingkan dan materi yang ditambahkan. Kurikulum 2013 ini pembelajarannya berpusat pada siswa, siswa yang dituntut lebih aktif daripada guru, sehingga menuntut guru agar bisa lebih kreatif dalam merancang pembelajaran agar menjadi aktif, kreatif, inovatif dan berpusat pada siswa. Kegiatan pembelajaran pada kurikulum 2013 dikombinasikan dengan penggunaan model untuk mencapai tujuan pembelajaran yang disesuaikan dengan karakteristik dan kebutuhan siswa dalam kegiatan pembelajaran.

Karakteristik dan kebutuhan siswa antara satu dengan yang lainnya berbeda-beda, namun dapat dikelompokkan berdasarkan jenjang pendidikan yang ditempuh. Sudarwa (2010:64) menyatakan bahwa "perkembangan kognitif yang terjadi pada anak usia sekolah dasar disebut sebagai tahap operasi konkret". Pada masa operasi konkret anak tidak bisa berpikir baik secara logis maupun abstrak. Anak usia ini dibatasi untuk berpikir konkret, pasti, tepat, istilah yang lebih menunjukkan pengalaman nyata. Maka dari itu guru harus bisa merancang pembelajaran yang lebih nyata dalam setiap kegiatan pembelajaran misalnya menggunakan alat bantu seperti media pembelajaran ataupun bisa juga dengan menghubungkan dengan pengalaman nyata dilingkungan tempat siswa tinggal. Terdapat beberapa muatan materi pembelajaran yang berisi ilmu untuk diperkenalkan pada siswa, salah satunya ilmu pengetahuan yang ada diantaranya yaitu pembelajaran IPA atau yang sering disebut dengan Ilmu Pengetahuan Alam atau Sains pada jenjang Sekolah Dasar. Sains atau IPA merupakan suatu konsep ilmu yang mempelajari keadaan, hubungan atau keterkaitan alam semesta yang tidak dapat dipisahkan antara satu dengan yang lainnya. Pendapat (Susanto, 2012:167) Sains atau IPA adalah "usaha manusia dalam memahami alam semesta melalui pengamatan yang tepat pada sasaran, serta menggunakan prosedur, dan dijelaskan dengan penalaran sehingga mendapatkan suatu kesimpulan".

Shoimin (2014) menyatakan bahwa model pembelajaran Snowball Throwing merupakan bagian dari model pembelajaran kooperatif. Hanya saja, pada model ini, kegiatan belajar diatur sedemikian rupa sehingga proses belajar mengajar dpat berlangsung dengan lebih menyenangkan. Dengan penerapan model ini, diskusi kelompok dan interaksi antar siswa dari kelompok yang berbeda memungkinkan terjadinya saling shering pengetahuan dan pengalaman dalam upaya menyelesaikan permasalahan yang mungkin timbul dalam diskusi yang berlangsung secara lebih interaktif dan menyenangkan.

Susanto (2013:5) berpendapat bahwa "IPA adalah usaha manusia dalam memahami alam semesta melalui pengamatan yang tepat pada sasaran, serta menggunakan prosedur, dan dijelaskan dengan penalaran sehingga mendapatkan simpulan". Berdasarkan pengertian tersebut, IPA dapat dibagi menjadi tiga, yaitu IPA sebagai Produk, IPA sebagai Proses, dan sikap. Sikap-sikap yang dimaksud adalah sikap ilmiah yang dimiliki oleh ilmuan. Jadi IPA sangat penting diajarkan kepada siswa dimulai dari jenjang Pendidikan dasar. Melalui mata pelajaran IPA, siswa dilatih untuk memiliki keterampilan mengamati dan bereksperimen. Dalam pembelajran IPA, siswa juga dilatih untuk memiliki sikap ilmiah seperti sikap jujur sehingga dalam proses pembelajaran IPA seorang guru harus mampu mengajarkan materi dan membentuk siksap siswa. Selain itu, Pendidikan IPA menjadi dasar pemikiran siswa dalam memahami hal-hal terkait gejala-gejala alam yang terjadi di sekitar mereka.

Berdasarkan wawancara yang dilakukan dengan wali kelas III di SD Gugus IV Kecamatan Sawan pada tanggal 10 sampai 15 Januari 2019, ada beberapa kendala yang sering dihadapi guru dalam proses pembelajaran yaitu, (1) siswa cenderung pasif di kelas, kurangnya perhatian siswa terhadap materi yang di jelaskan oleh guru, (2) waktu yang digunakan tidak cukup untuk menyampaikan materi pelajaran yang padat, (3) sekolah tidak menyediakan media pembelajaran.

Setelah kegiatan wawancara, dilaksanakan kegiatan observasi langsung pada saat pelaksanaan pembelajaran pada mata pelajaran IPA di kelas III yang dilaksanakan di Gugus IV Kecamatan Sawan, didapatkan fakta yaitu, (1) Guru dalam melaksanakan pembelajaran cenderung menggunakan metode ceramah dan siswa hanya sebagai penerima informasi sehingga siswa menjadi pasif dan tidak 
mempunyai kesempatan menyampaikan argumen atau pendapat terkait materi yang sedang dipelajari. (2) Guru tidak menggunakan media dan alat peraga pada saat pelaksanaan pembelajaran sehingga pembelajaran yang terjadi di dalam kelas kurang menarik bagi siswa. (3) Sumber belajar yang digunakan guru dalam pembelajaran sebagian besar berpatokan pada satu sumber saja.

Sesuai dengan permasalahan yang telah di uraikan, maka perlu adanya solusi agar pembelajaran dapat berjalan dengan maksimal dan mampu meningkatkan hasil belajar siswa. Salah satunya adalah menggunakan model pembelajaran. Model pembelajaran merupakan kerangka konseptual yang melukiskan prosedur yang sistematis dalam mengorganisasi pengalaman belajar untuk mencapai tujuan belajar (Agustiana, 2013:332).

Salah satu model pembelajaran yang dapat digunakan yaitu model pembelajaran Snowball Throwing. Snowball Throwing adalah "pengembangan dari model pembelajaran diskusi dan merupakan bagian dari model pembelajaran kooperatif" (Shoimin, 2014:226). Sedangkan menurut Kurniasih \& Berlin (2016:77) model pembelajaran Snowball Throwing 'bola salju bergulir' merupakan "model pembelajaran dengan menggunakan bola pertanyaan dari kertas yang digulung bulat berbentuk bola kemudian dilemparkan secara bergiliran di antara sesama anggota kelompok".

Model pembelajaran Snowball Throwing akan lebih maksimal jika berlandaskan dengan Tri Hita Karana. Tri Hita Karana merupakan tiga jenis kebahagiaan hidup manusia dalam ajaran Agama Hindu yang artinya hubungan manusia dengan Tuhan (parahyangan), hubungan antar manusia (pawongan), hubungan manusia dengan lingkungan (palemahan). Sejalan dengan pendapat (Wirawan, 2011) menyatakan Tri Hita Karana artinya tiga hal pokok yang menjadi penyebab kebahagiaan dalam hidup manusia.

Dengan konsep tersebut maka siswa dalam pembelajaran akan mengamalkan makna dari pedoman hidup umat Hindu Khusunya di Bali, sehingga pembelajaran menjadi lebih baik dan dapat tercapainya tujuan pembelajaran secara maksimal. Maka dari itu, model pembelajaran Snowball Throwing Berbasis Tri Hita Karana sangat baik diterapkan dalam proses pembelajaran IPA di SD karena akan dapat meningkatkan hasil belajar IPA siswa.

Dari uraian tersebut, maka penting untuk dilakukan suatu penelitian eksperimen yang berjudul Pengaruh Model Pembelajaran Snowball Throwing Berbasis Tri Hita Karana Terhadap Hasil Belajar IPA Kelas III SD Gugus IV Kecamatan Sawan Kabupaten Buleleng Tahun ajaran 2018/2019.

\section{METODE}

Penelitian ini merupakan jenis penelitian eksperimen semu (quasi eksperiment) karena tidak semua variabel dapat dikontrol secara ketat. Penelitian ini menggunakan rancangan Non Equivalent Posttest Only Control Group Design. Populasi dalam penelitian ini adalah seluruh siswa kelas III di Gugus IV Kecamatan Sawan Kabupaten Buleleng. Adapun sebaran siswa kelas III di Gugus VII Kecamatan Sawan Kabupaten Buleleng. Untuk mengetahui kemampuan di masing-masing siswa SD di Kecamatan Sawan setara atau tidak, maka seluruh anggota populasi diuji kesetaraan kemampuannya dengan cara menganalisis nilai Ulangan Akhir Semester mata pelajaran IPA menggunakan rumus Anava satu jalur. Teknik pengambilan sampel yang digunakan dalam penelitian ini adalah teknik random sampling dengan cara undian. Alasan pengambilan sampel dengan cara undian karena cara ini cukup sederhana dan memungkinkan ketidakadilan dapat dihindari. Keenam sekolah yang setara selanjutnya akan diadakan pengundian secara acak untuk menentukan dua kelas yaitu sebagai sampel. Setelah mengetahui dua kelompok sampel dilakukan pengundian kembali untuk menentukan kelas eksperimen dan kelas kontrol. Hasil pengundian tersebut adalah SD Negeri 2 Bungkulan sebagai kelas eksperimen dan SD Negeri 4 Bungkulan sebagai kelas kontrol.

Pengumpulan data dalam penelitian ini menggunakan instrumen tes. Data yang diperlukan dalam penelitian ini adalah kemampuan hasil belajar siswa pada mata pelajaran IPA. Untuk mengumpulkan data hasil belajar siswa, maka digunakan instrumen tes objektif sebanyak 40 butir. Tes obyekif ini dipilih dengan asumsi bahwa dengan menjawab tes ini, siswa mampu memilih dan memahami jawaban yang mana yang tepat dalam pertanyaan yang dituliskan, serta untuk menilai hasilnya menggunakan poin benar salah jika dijawab benar mendapat poin 1 dan jika salah mendapat poin 0 . Instrumen tersebut terlebih dahulu dianalisis dengan menggunakan uji validitas, reliabilitas tes, taraf kesukaran tes, dan daya beda tes. Teknik analisis data yang digunakan dalam penelitian ini yaitu analisis deskriptif, uji persyarat, dan uji hipotesis. Uji hipotesis yang digunakan adalah uji-t. 
Sebelum melakukan uji-t, terlebih dahulu dilakukan analisis uji persyarat yang meliputi uji normalitas dan uji homogenitas.

\section{HASIL DAN PEMBAHASAN}

Data penelitian ini adalah skor hasil belajar siswa sebagai akibat dari penerapan Model Pembelajaran Snowball Throwing Berbasis Tri Hita Karana pada kelompok eksperimen dan bukan penerapan Model Pembelajaran Snowball Throwing Berbasis Tri Hita Karana pada kelompok kontrol. Hasil post-test terhadap 26 orang siswa kelompok eksperimen menunjukkan bahwa skor tertinggi adalah 27 dan skor terendah adalah 8. Berdasarkan Tabel 4.1, dapat dideskripsikan mean (M), median (Md), modus (Mo), varians, dan standar deviasi (s) dari data hasil belajar kelompok eksperimen, yaitu: mean $(\mathrm{M})=18,04$; median $(\mathrm{Md})=18,5$; $\operatorname{modus}(\mathrm{Mo})=20,02$; varians $\left(\mathrm{s}^{2}\right)=23,56$; dan standar deviasi $(\mathrm{s})=4,85$. Sedangkan hasil post-test terhadap 30 orang siswa kelompok kontrol menunjukkan bahwa skor tertinggi adalah 25 dan skor terendah adalah 6. Berdasarkan Tabel 4.1 dapat dideskripsikan mean (M), median (Md), modus (Mo), varians, dan standar deviasi (s) dari data hasil belajar kelompok eksperimen, yaitu: mean $(\mathrm{M})=15,23$; median $(\mathrm{Md})=14,98$; modus $(\mathrm{Mo})=14,5$; varians $\left(\mathrm{s}^{2}\right)=18,63$; dan standar deviasi (s) = 4,32.

Berdasarkan hasil konversi diperoleh bahwa skor rata-rata hasil belajar siswa kelompok eksperimen dengan $\mathrm{M}=18,04$ tergolong kriteria tinggi. Hal tersebut juga secara jelas dan digambarkan pada kurve polygon di bawah ini.

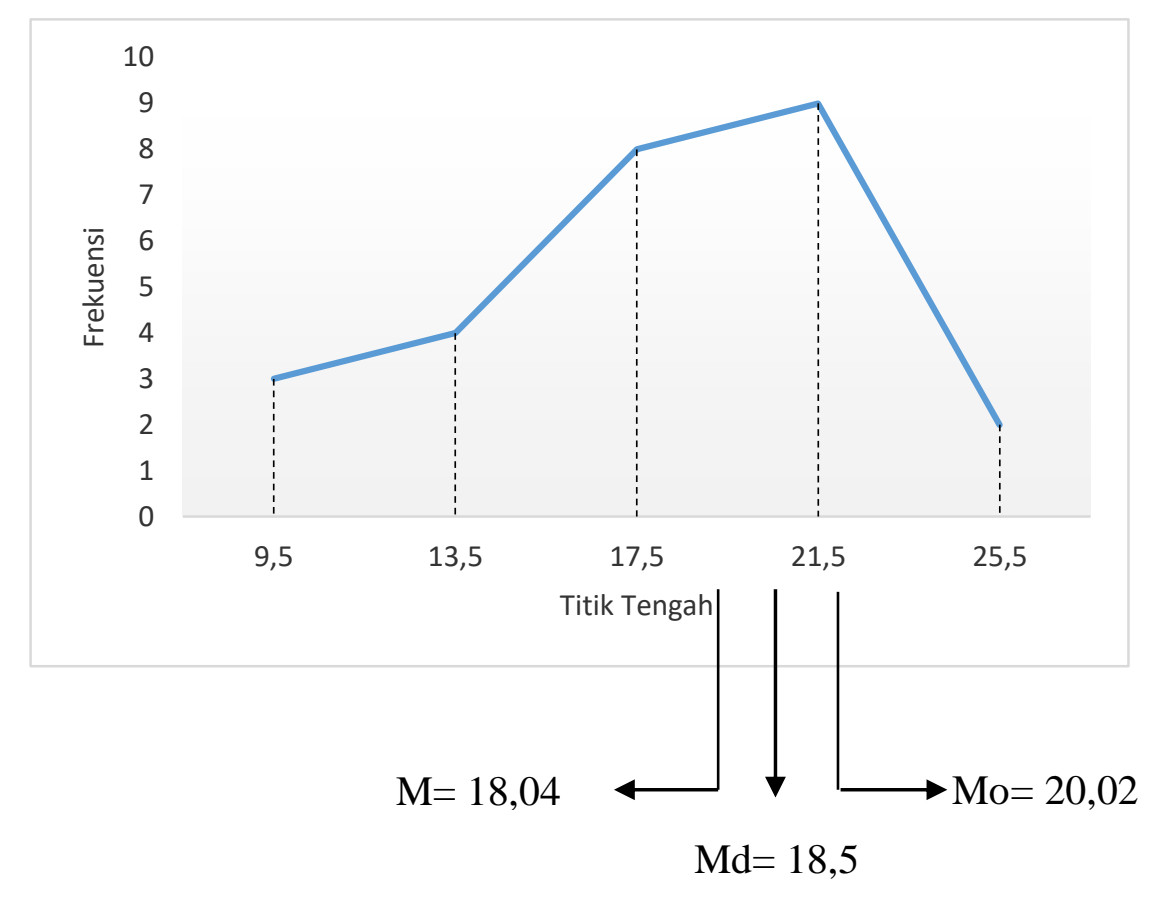

\section{Gambar 1. Kurva Poligon Data Hasil Belajar IPA Siswa Kelompok Eksperimen}

Berdasarkan kurva tersebut, tampak bahwa sebaran data kelompok siswa yang mengikuti model pembelajaran Snowball Throwing Berbasis Tri Hita Karana merupakan kurva juling negatif karena Mo $>\mathrm{Md}>\mathrm{M}(20,02>18,5>18,04)$. Hal ini menunjukkan bahwa sebagian besar skor siswa kelompok eksperimen cenderung tinggi.

Pada kelompok kontrol diperoleh bahwa skor rata-rata hasil belajar siswa kelompok kontrol dengan $\mathrm{M}=15,23$ tergolong kriteria sedang. Perbandingan hasil perhitungan rata-rata hasil belajar kelompok ekperimen adalah 18,04 lebih besar dari rata-rata hasil belajar kelompok kontrol sebesar 15,23. Hal tersebut juga secara jelas dan digambarkan pada kurve polygon di bawah ini. 


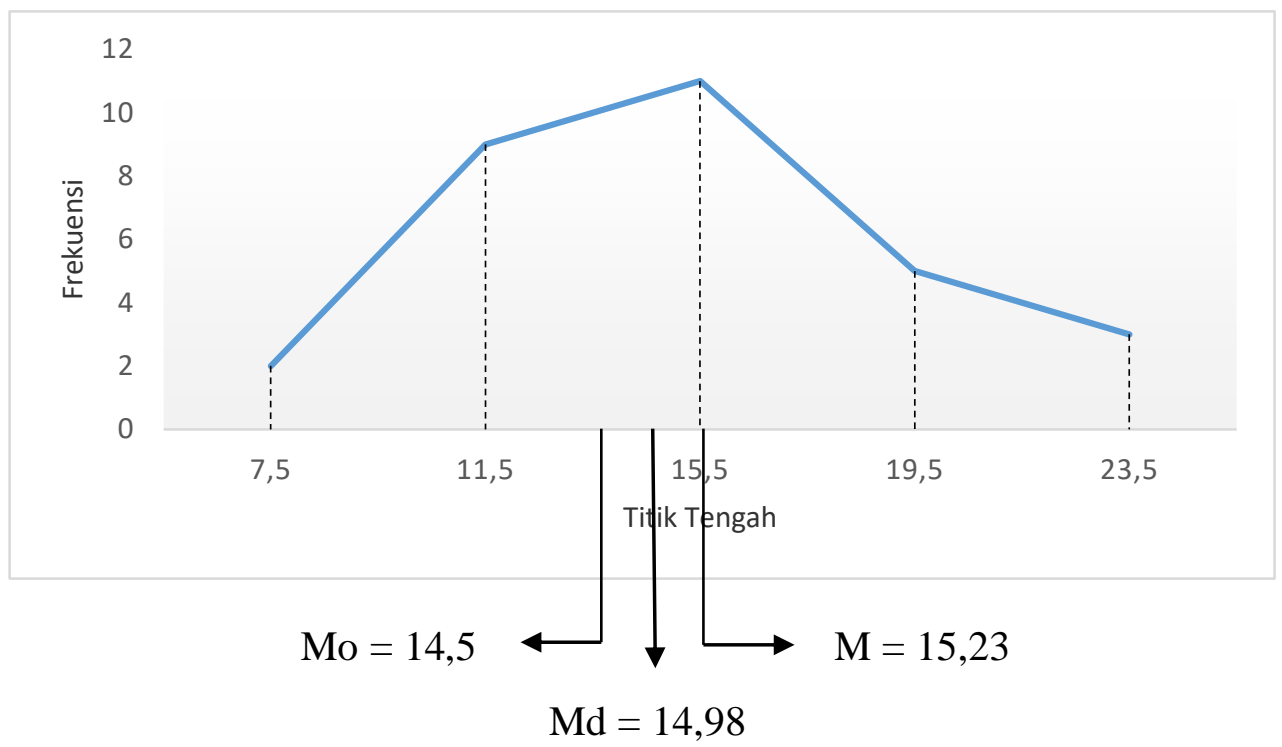

\section{Gambar 2. Kurva Poligon Data Hasil Belajar IPA Siswa Kelompok Kontrol}

Kurva di atas menunjukkan bahwa kurva sebaran data kelompok siswa yang mengikuti pembelajaran tidak menggunakan model pembelajaran NHT berupa kurva juling positif karena Mo < $\mathrm{Md}<\mathrm{M}(14,5<14,98<15,23)$. Hal ini menunjukkan bahwa sebagian besar skor siswa kelompok kontrol cenderung sedang.

Sebelum dilakukannya uji hipotesis terlebih dahulu dilakukan uji normalitas dan homogenitas data. Adapun hasil uji normalitas dan homogenitas data disajikan pada tabel 1 dan tabel 2.

Tabel 1. Hasil Uji Normalitas Sebaran Data Hasil Belajar IPA

\begin{tabular}{clccc}
\hline No & $\begin{array}{c}\text { Kelompok Data Hasil } \\
\text { belajar IPA }\end{array}$ & $\chi^{2}$ & $\begin{array}{c}\text { Nilai Kritis pada Taraf } \\
\text { Signifikansi 5\% }\end{array}$ & Status \\
\hline 1 & Eksperimen & 2,127 & 5,99 & Normal \\
2 & Kontrol & 1,863 & 5,99 & Normal \\
\hline
\end{tabular}

Tabel 2. Hasil Uji Homogenitas Kelompok Eksperimen dan Kontrol

\begin{tabular}{lccc}
\hline Kelompok Data Hasil belajar IPA & F-hitung & F-tabel dengan Taraf Signifikansi 5\% & Status \\
\hline $\begin{array}{l}\text { Eksperimen } \\
\text { Kontrol }\end{array}$ & 0,461 & 3,841 & Homogen \\
\hline
\end{tabular}

Berdasarkanan uji normalitas dan homogenitas diperoleh bahwa dari hasil perhgitungan data hasil belajar matematika adalah normal dan homogen, sehingga uji hipotesis dengan uji $t$ bisa dilakukan. Hasil analisis data menggunakan uji-t, tampak bahwa $t_{\text {hitung }}$ sebesar 2,533 , sedangkan, $t_{\text {tabel }}$ dengan $\mathrm{dk}=54$ pada taraf signifikansi $5 \%$ adalah 2,0. Hal ini berarti, $t_{\text {hitung }}$ lebih besar dari $t_{\text {tabel }}\left(t_{\text {hitung }}>\right.$ $\left.t_{\text {tabel}}\right)$ sehingga $\mathrm{H}_{0}$ ditolak dan $\mathrm{H}_{1}$ diterima. Dengan demikian, dapat diinterpretasikan bahwa terdapat perbedaan yang signifikan pada hasil belajar IPA antara siswa yang belajar dengan Model Pembelajaran Snowball Throwing Berbasis Tri Hita Karana dan siswa yang tidak belajar dengan Model Pembelajaran Snowball Throwing Berbasis Tri Hita Karana pada siswa kelas III SD di Gugus IV Kecamatan Sawan Tahun Pelajaran 2016/2017.

Model Pembelajaran Snowball Throwing Berbasis Tri Hita Karana digunakan pada kelompok eksperimen dan pada kelompok kontrol yang tidak menggunakan Model Pembelajaran Snowball 
Throwing Berbasis Tri Hita Karana dalam penelitian ini menunjukkan pengaruh yang berbeda pada hasil belajar IPA siswa. Hal tersebut dipengaruhi oleh dua faktor..

Faktor pertama, Model Pembelajaran Snowball Throwing Berbasis Tri Hita Karana dapat melatih siswa untuk berpikir sendiri, berdiskusi, disiplin siswa dalam melempar maupun menangkap soal dan menyampaikan hasil diskusinya terkait konsep-konsep IPA yang dipelajari. Kegiatan berpikir mampu mengarahkan siswa untuk mengeluarkan kemampuannya dalam memecahkan sebuah permasalahan. Kegiatan diskusi terlihat mampu menambah keyakinan siswa terhadap hasil pemikirannya. Selanjutnya, kegiatan menyampaikan hasil pemikiran kepada teman sekelasnya akan menambah ingatan siswa terkait pemahamannya terhadap konsep. Ketiga kegiatan tersebut dapat memotivasi siswa untuk belajar lebih baik dan menemukan hal-hal yang bermakna dari kegiatan tersebut. Hal ini sejalan dengan pendapat Akhiriyah (2011) yang menyatakan bahwa model pembelajaran Snowball Throwing akan menciptakan suasana yang menyenangkan dalam proses belajar dan membangkitkan motivasi siswa dalam belajar. Melalui model pembelajaran Snowball Throwing pemahaman yang diperoleh tersebut tidak mudah dilupakan karena proses yang siswa lalui untuk memperolehnya merupakan kegiatan pembelajaran yang bermakna. Temuan penelitian ini juga di dukung oleh penelitian yang relevan yang dilakukan oleh Dewi (2013) dengan hasil bahwa model pembelajaran Snowball Throwing sangat berpengaruh terhadap hasil belajar IPA dibandingkan dengan model konvensional. Melalui model Snowball Throwing siswa dapat melakukan kegiatan mengeksplorasi pengetahuan awal dan pengalaman serta melakukan diskusi kelompok untuk percobaan dan pengamatan.

Faktor kedua, faktor kedua yang mempengaruhi perbedaan hasil belajar siswa yaitu Tri Hita Karana kesan yang berbeda pada pembelajaran. Tri Hita Karana merupakan kearifan lokal yang ada dalam masyarakat Bali yang dijadikan sebagai pedoman dalam kehidupan bermasyarakat. Sebelum proses pembelajaran dilaksanakan terlebih dahulu siswa berdoa bersama, begitu juga setelah proses pembelajaran juga diakhiri dengan berdoa bersama. Hal tersebut mencerminkan bagian dari Tri Hita Karana yang pertama yaitu prahyangan. Selanjutnya dilakukan proses pembelajaran dengan mengintruksikan siswa untuk membuat pertanyaan dalam kertas dan melemparkan pertanyaan tersebut merupakan implementasi dari pawongan. Kegiatan tersebut termasuk pawongan karena terjalin interaksi kerja kelompok dan kegiatan melempar bola pertanyaan antar siswa. Setelah selesai berdiskusi sebelum pembelajaran diakhiri, siswa membersihkan kertas - kertas pertanyaan yang berserakan sehingga lingkungan menjadi bersih kembali. Hal tersebut merupakan bagian yang ke tiga yaitu pelemahan. Dengan diterapkannya Tri Hita Karana dalam proses pembelajaran, proses pembelajaran menjadi berjalan dengan sangat harmonis karena terjadi keseimbangan antara siswa dengan Tuhan, siswa dengan siswa yang lainnya dan siswa dengan dengan lingkungan sekitarnya. Hal tersebut sejalan dengan pendapat (Wirawan, 2011) yang menyatakan bahwa Tri Hita Karana merupakan tiga hal pokok yang menjadi penyebab kebahagiaan dalam hidup manusia.

Berdasarkan paparan di atas, maka dapat disimpulkan bahwa model pembelajaran snowball throwing berbasis tri hita karana berpengaruh terhadap hasil belajar IPA siswa.

\section{SIMPULAN}

Hasil uji-t menunjukkan bahwa sebesar 2,533, sedangkan, $t_{\text {tabel }}$ dengan $\mathrm{dk}=54$ pada taraf signifikansi $5 \%$ adalah 2,0. Hal ini berarti, $t_{\text {hitung }}$ lebih besar dari $t_{\text {tabel }}\left(t_{\text {hitung }}>t_{\text {tabel }}\right)$ sehingga $H_{0}$ ditolak dan $\mathrm{H}_{1}$ diterima. Dengan demikian, dapat diinterpretasikan bahwa terdapat perbedaan yang signifikan pada hasil belajar IPA antara siswa yang belajar dengan Model Pembelajaran Snowball Throwing Berbasis Tri Hita Karana dan siswa yang tidak belajar dengan Model Pembelajaran Snowball Throwing Berbasis Tri Hita Karana pada siswa kelas III SD di Gugus IV Kecamatan Sawan Tahun Pelajaran 2018/2019. Beberapa saran yang dapat diajukan guna peningkatan kualitas pembelajaran di SD adalah sebagai berikut (1) siswa agar lebih termotivasi dalam mengikuti pembelajaran yang diberikan guru, sehingga dapat meningkatkan hasil belajar pada setiap mata pelajaran. (2) guru disarankan agar menerapkan model pembelajaran Snowball Throwing Berbasis Tri Hita Karana karena hasil penelitian membuktikan bahwa model pembelajaran Snowball Throwing Berbasis Tri Hita Karana mampu meningkatkan hasil belajar siswa. (3) Kepala sekolah agar dapat menggunakan hasil penelitian ini sebagai bahan acuan pedoman untuk membimbing guru-guru dalam melaksanakan pembelajaran 
dengan menggunakan model pembelajaran untuk meningkatkan hasil belajar dan motivasi berprestasi siswa. (4) Peneliti lain agar hasil penelitian ini dapat digunakan sebagai acuan kepustakaan untuk melakukan penelitian dalam variabel yang sama ataupun pada variabel yang berbeda.

\section{UCAPAN TERIMAKASIH}

Dalam kegiatan penelitian ini diucakan terimakasih atas segala dukungan dan bantuan yang telah diberikan untuk peneliti sehingga penelitian ini bisa berjalan dengan lancar. Tidak lupa pula peneliti mengucapkan rasa syukur yang mendalam ke hadapan Tuhan Yang Maha Esa, karena berkat tuntunan beliau peneliti telah diberikan kebudahan dalam melaksanakan proses penelitian.

\section{DAFTAR PUSTAKA}

Dewi, M.P., Putra, I.K.A. and Negara, I.G.A.O., 2013. Pengaruh Model Pembelajaran Snowball Throwing terhadap Hasil Belajar IPA Siswa Kelas V SD di Gugus Sri Kandi Kecamatan Denpasar Timur. MIMBAR PGSD Undiksha,1(1).

Kurniasih, I. \& Berlin Sani. 2016. Ragam Pengembangan Model Pembelajaran untuk Peningkatan Profesionalitas Guru. Kata Pena.

Kusumayanti, D.P.Y., 2013. Pengaruh Model Pembelajaran Snowball Throwing Berbantuan Media Konkret Terhadap Hasil Belajar IPA Siswa Kelas V Di Gugus V Kecamatan Sukasada. Jurnal Mimbar PGSD. Singaraja: Universitas Pendidikan Ganesha.

Susanto, Ahmad. 2013. Teori Belajar dan Pembelajaran di Sekolah Dasar, Edisi 1, Cetakan Pertama. Jakarta: Kencana Prenadamedia Group.

Shoimin, A. 2014. 68 Model Pembelajaran Inovatif dalam Kurikulum 2013. Yogyakarta: Ar-Ruzz Media.

Wirawan. 2011. Evaluasi Teori Model Standar Aplikasi dan Profesi, Contoh Aplikasi Evaluasi Program: Pengembangan Sumber Daya Manusia, Program Nasional Pemberdayaan Masyarakat (PNPM) Mandiri Pedesaan, Kurikulum, Perpustakaan, dan Buku Tes. Jakarta: Raja Grafindo Persada. 